\title{
PENGARUH MODEL INQUiRY LEARNING TERHADAP KEMAMPUAN BERPIKIR Kritis MATEMATIS SiSWa PAda MATERI FungSi KuAdrat Kelas X SMA NEGERI 3 SINGKAWANG
}

\author{
Giyanti Prameswari ${ }^{1)}$, Ristia Apriana ${ }^{2)}$, Rika Wahyuni ${ }^{3)}$ \\ 1) Program Studi Pendidikan Matematika, STKIP Singkawang, Indonesia \\ E-mail : giyantip@gmail.com \\ 2) Program Studi Pendidikan Matematika, STKIP Singkawang, Indonesia \\ E-mail: rikawahyuni142@gmail.com \\ 3) Program Studi Pendidikan Matematika, STKIP Singkawang, Indonesia \\ E-mail: rikawahyuni142@gmail.com
}

\begin{abstract}
Abstrak. Penelitian ini bertujuan untuk mengetahui pengaruh model inquiry learning terhadap kemampuan berpikir kritis matematis siswa. Jenis penelitian yang digunakan adalah kuantitatif eksperimen dengan desain True Eksperimental Design dengan bentuk desain Post-test Only Control Design. Instrumen yang digunakan dalam penelitian ini adalah tes kemampuan berpikir kritis matematis, angket motivasi belajar siswa, dan lembar observasi keterlaksanaan model inquiry learning. Teknik analisis data yang digunakan dalam penelitian untuk mengetahui pengaruh model inquiry learning terhadap kemampuan berpikir kritis matematis digunakan rumus Effect Size, untuk mengetahui pengaruh model inqiry learning terhadap motivasi belajar siswa dan keterlaksanaan model inquiry learning dianalisis secara deskriptif menggunakan persentase rata-rata. Berdasarkan hasil analisis data disimpulkan bahwa: 1) Terdapat pengaruh model inquiry learning terhadap kemampuan berpikir kritis matematis siswa yaitu nilai Effect Size yaitu sebesar 0,9 yang berada pada kriteria tinggi; 2) Model inquiry learning memberikan pengaruh yang lebih baik terhadap motivasi belajar siswa karena persentase rata-rata motivasi belajar siswa yang diajarkan dengan model inquiry learning sebesar 81,64\% dengan kriteria sangat tinggi sedangkan persentase ratarata motivasi belajar siswa yang diajarkan dengan model pembelajaran langsung sebesar 69,28\% dengan kriteria tinggi; 3) Keterlaksanaan model inquiry learning terlaksana dengan sangat baik dengan persentase keterlaksanaan model inquiry learning sebesar $81,44 \%$ memiliki kriteria sangat baik.
\end{abstract}

Kata kunci: model inquiry learning, kemampuan berpikir kritis matematis, motivasi belajar

\section{PENDAHULUAN}

Berpikir kritis merupakan sebuah proses sistematis yang memungkinkan siswa untuk merumuskan dan mengevaluasi keyakinan dan pendapat mereka sendiri (Johnson, 2014: 185). Kemampuan berpikir kritis merupakan kemampuan yang perlu dimiliki oleh siswa dalam menghadapi permasalahan. Menurut Johnson (2014: 185) berpikir kritis adalah sebuah proses terorganisasi yang memungkinkan siswa mengevaluasi bukti, asumsi, logika, dan bahasa yang mendasari pernyataan orang lain. Maka berpikir kritis juga dapat diartikan sebagai kemampuan menganalisis suatu permasalahan. Sesuai dengan hal tersebut dalam pembelajaran matematika, kemampuan berpikir kritis siswa sangat penting.
Dengan berpikir kritis, siswa akan berusaha menemukan masalah dan berusaha menyelesaikannya. Dari pemaparan di atas maka dapat disimpulkan bahwa kemampuan berpikir kritis merupakan faktor yang berpengaruh dalam pembelajaran matematika.

Berdasarkan pengamatan yang dilakukan pada kelas $\mathrm{X}$ SMA Negeri 3 Singkawang, dalam proses pembelajaran matematika ditemukan masalah yaitu siswa terkadang sibuk sendiri saat guru menerangkan, siswa sibuk menyalin apa yang ditulis dan diungkapkan guru, apabila ditanya siswa menjawab secara bersamaan, siswa akan kebingungan apabila diberi soal latihan yang berbeda dengan contoh yang diberikan guru, kebiasaan siswa meniru contoh penyelesaian soal yang diberikan guru tanpa mempunyai keinginan untuk 
menyelesaikan soal dengan cara yang berbeda, dan motivasi siswa terhadap pembelajaran matematika masih sangat kurang hal ini terjadi karena anggapan siswa tentang mata pelajaran matematika yang sulit dan tidak mudah dimengerti. Beberapa masalah yang dipaparkan terlihat bahwa kemampuan berpikir kritis siswa rendah karena dalam proses pembelajaran siswa cenderung hanya menerima materi yang diajarkan tanpa adanya keinginan untuk menelaah lebih dalam dan berkelanjutan.

Rendahnya kemampuan berpikir kritis matematis siswa juga terlihat dari hasil prariset. Soal prariset yang diberikan kepada 33 siswa kelas X MIPA 3 adalah materi persamaan kuadrat. Ditemukan bahwa: 1) Siswa yang tidak dapat mengidentifikasi asumsi yang diberikan sebanyak 29 orang atau $87,88 \%$; 2) Siswa yang tidak dapat menemukan cara yang dapat dipakai untuk menyelesaikan masalah sebanyak 30 siswa atau 90,91\%; 3) Siswa yang tidak dapat mengungkapkan konsep/teorema/definisi dan menggunakannya dalam menyelesaikan masalah sebanyak 29 siswa atau $87,88 \%$.

Dari masalah yang dipaparkan, terlihat bahwa cara berpikir kritis matematis siswa rendah karena tidak dapat memenuhi indikator dari kemampuan berpikir kritis matematis. Hal ini sejalan dengan penelitian Fahrunnisak (2014) yang memaparkan bahwa kemampuan berpikir kritis siswa rendah karena siswa tidak dapat mengidentifikasi asumsi, tidak mampu menentukan solusi dari permasalahan dalam soal dengan benar, tidak mampu menentukan kesimpulan, dan tidak mampu menentukan alternatif cara lain dalam menyelesaikan masalah. Oleh karena itu, guru harus bisa mengembangkan kemampuan berpikir kritis siswa dalam memahami pelajaran.

Satu di antara materi yang hampir sama dengan persamaan kuadrat adalah fungsi kuadrat. Materi persamaan kuadrat dan fungsi kuadrat merupakan materi yang saling berkaitan. Jika kemampuan berpikir kritis matematis siswa pada materi persamaan kuadrat rendah, kemungkinan hal ini juga akan terjadi saat siswa mempelajari materi fungsi kuadrat yang akan dipelajari pada semester genap tahun ajaran 2015/2016. Sehingga guru perlu menggunakan model pembelajaran yang efektif agar siswa memiliki motivasi untuk mempelajari materi yang diberikan.

Hal ini sejalan dengan tema yang dikemukan Bruner (dalam Syaifurahman dan Ujiati, 2013: 58) yang salah satunya adalah guru diharapkan dapat menggunakan metode pembelajaran yang cocok agar dapat meningkatkan motivasi siswa. Usaha-usaha dalam membelajarkan siswa merupakan bagian yang sangat penting dalam mencapai keberhasilan tujuan pembelajaran yang sudah direncanakan. Satu di antara tujuan dari model pembelajaran adalah untuk meningkatkan kemampuan berpikir siswa selama belajar. Satu di antara model pembelajaran yang efektif untuk meningkatkan kemampuan berpikir siswa adalah cooperative learning.

Menurut Johnson (Isjoni, 2014: 24-25) cooperative learning juga menghasilkan peningkatan kemampuan akademik, meningkatkan kemampuan berpikir kritis, membentuk hubungan persahabatan, menimba berbagai informasi, belajar menggunakan sopan-santun, meningkatkan motivasi siswa, memperbaiki sikap terhadap sekolah dan belajar mengurangi tingkah laku yang kurang baik, serta membantu siswa dalam menghargai pokok pikiran orang lain. Satu di antara tipe model pembelajaran kooperatif adalah inquiry learning. Model pembelajaran inkuiri (inquiry learning) dapat mendorong siswa untuk aktif dalam proses pembelajaran. Model inquiry learning merupakan model pembelajaran yang menekankan pada proses berpikir kritis dan analisis untuk mencari dan menemukan jawaban dari suatu masalah yang dipermasalahkan. Model ini juga merupakan satu di antara model yang diterapkan dalam kurikulum 2013.

Model inquiry learning menekankan pada proses mencari dan menemukan. Materi pelajaran tidak diberikan secara langsung. Peran siswa dalam pembelajaran ini adalah mencari dan menemukan sendiri materi pelajaran, sedangkan guru berperan sebagai fasilitator dan pembimbing siswa untuk belajar. Sehingga diharapkan model inquiry learning dapat mempengaruhi kemampuan berpikir kritis matematis siswa. Hal ini sejalan dengan penelitian yang dilakukan Wahyudi (2013) menunjukkan bahwa kelas eksperimen mampu mendapatkan hasil berpikir kritis yang lebih baik dengan adanya perlakuan pembelajaran inquiry dibandingkan dengan kelas kontrol tanpa adanya pembelajaran inquiry.

Berdasarkan pemaparan di atas, penulis ingin mengetahui pengaruh model inquiry learning dalam pembelajaran matematika terhadap kemampuan berpikir kritis matematis siswa dengan melakukan penelitian dengan judul "Pengaruh Model Inquiry Learning Terhadap Kemampuan Berpikir Kritis Matematis Siswa Pada Materi Fungsi Kuadrat Kelas X SMA Negeri 3 Singkawang". Adapun sub-sub rumusan masalah dalam penelitian ini adalah 1) Apakah terdapat pengaruh model inquiry learning terhadap kemampuan berpikir kritis siswa pada materi fungsi kuadrat SMA Negeri 3 Singkawang ?; 2) Bagaimana pengaruh model inquiry learning terhadap motivasi belajar siswa pada materi fungsi kuadrat ?; 3) Bagaimana keterlaksanaan model inquiry learning pada materi fungsi kuadrat ?

\section{Metode Penelitian}

Jenis penelitian ini adalah kuantitatif eksperimen dengan desain True Eksperimental Design dalam bentuk desain Posttest Only Control Design. Populasi dalam penelitian ini adalah 
siswa kelas X MIPA SMA Negeri 3 Singkawang yaitu X MIPA 1, X MIPA 2, dan X MIPA 3. Sampel yang digunakan adalah X MIPA 3 sebagai kelas eksperimen dan X MIPA 1 sebagai kelas kontrol. Teknik pengambilan sampel adalah dengan Simple Random Sampling setelah populasi dinyatakan homogen.

Teknik pengumpulan data yang digunakan dalam penelitian ini adalah sebagai berikut; a) Teknik pengukuran, teknik pengukuran yang dimaksud adalah tes kemampuan berpikir kritis matematis siswa yang berbentuk uraian; b) Teknik komunikasi tidak langsung, teknik komunikasi tidak langsung yang dimaksud adalah angket yang disebarkan kepada kelas eksperimen dan kelas kontrol; c) Teknik observasi langsung, teknik observasi langsung dalam penelitian ini adalah untuk mengetahui keterlaksanaan model inquiry learning.

Instrumen pengumpulan data yang digunakan dalam penelitian ini sebagai berikut: a) Tes kemampuan berpikir kritis matematis digunakan untuk mengetahui kemampuan berpikir kritis matematis sesudah diberikan perlakuan terdiri dari 6 soal uraian; b) Lembar angket, lembar angket digunakan untuk mengetahui motivasi belajar siswa setelah diberikan perlakuan; c) Lembar observasi, lembar observasi ini digunakan untuk mengetahui keterlaksanaan model inquiry learning yang diisi oleh seorang guru Matematika dan 2 orang mahasiswa STKIP Singkawang. Sebelum tes digunakan untuk penelitian, tes kemampuan berpikir kritis diuji cobakan terlebih dahulu di SMA Negeri 1 Singkawang untuk mengetahui kevalidan, reliabilitas, daya pembeda, dan tingkat kesukaran. Dari soal yang diuji cobakan soal nomor 1a, 1b, 1c, $2 \mathrm{a}, 2 \mathrm{~b}$, dan $2 \mathrm{c}$ adalah soal yang valid dengan reliabilitas yang sedang. Berdasarkan analisis tingkat kesukaran soal nomor 1a, 1b, 1c, 2a, 2b, dan 2c termasuk dalam kategori sedang. Selanjutnya berdasarkan daya pembeda soal nomor soal 1a, 1b, 2a, dan 2c memiliki daya pembeda sedang, sedangkan nomor soal $1 \mathrm{c}$ dan $2 \mathrm{~b}$ memiliki daya pembeda baik. Jadi, semua soal digunakan untuk penelitian.

Teknik analisis data yang digunakan untuk menjawab sub rumusan masalah dalam penelitian adalah sebagai berikut.

1) untuk menjawab sub rumusan masalah 1 yaitu untuk mengetahui pengaruh model inquiry learning terhadap kemampuan berpikir kritis matematis siswa digunakan rumus Effect Size. Adapun rumusnya sebagai berikut.

$$
E S=\frac{\bar{Y}_{E}-\bar{Y}_{C}}{s_{C}}
$$

(Sumarni, 2014)

Keterangan:

ES = Effect Size

$\bar{Y}_{E}=$ Rata-rata kelas eksperimen

$\bar{Y}_{C}=$ Rata-rata kelas kontrol

$S_{C}=$ Standar Deviasi kelas Kontrol
TABEL I

KRITERIA EFFECT SIZE

\begin{tabular}{cc}
\hline$E S$ & Kriteria \\
\hline $\mathrm{ES}<0,2$ & Rendah \\
$0,2 \leq \mathrm{ES}<0,8$ & Sedang \\
$\mathrm{ES} \geq 0,8$ & Tinggi \\
\hline
\end{tabular}

Mulyatiningsih (dalam Sumarni, 2014)

Setelah dilakukan perhitungan menggunakan rumus Effect Size maka akan dilihat kriteria Effect Size pada Tabel 1 model inquiry learning dikatakan berpengaruh apabila berada pada kriteria rendah, sedang, dan tinggi.

2) untuk menjawab sub rumusan masalah 2 yaitu untuk mengetahui pengaruh model inquiry learning terhadap motivasi belajar siswa setelah diberikan perlakuan pada kelas eksperimen dan kelas kontrol maka dianalisis secara deskriptif menggunakan persentase rata-rata motivasi belajar siswa.

$$
P=\frac{S}{N} \times 100 \%
$$

Keterangan :

$P \quad=$ Persentase skor

$S \quad$ = skor yang diperoleh

$\mathrm{N} \quad=$ skor total

Kriteria persentase motivasi belajar siswa dapat dilihat pada Tabel II sebagai berikut.

TABEL II

KRITERIA PERSENTASE MOTIVASI BELAJAR SiswA

\begin{tabular}{cc}
\hline Presentase $(\%)$ & Kriteria \\
\hline $81,25<P \leq 100$ & Sangat Tinggi \\
$62,50<P \leq 81,25$ & Tinggi \\
$43,75<P \leq 62,50$ & Rendah \\
$25 \leq P \leq 43,75$ & Sangat Rendah \\
\hline
\end{tabular}

Berdasarkan Tabel II apabila kriteria motivasi belajar siswa kelas eksperimen lebih baik daripada kelas kontrol maka dapat disimpulkan bahwa model inquiry learning memberikan pengaruh yang lebih baik terhadap motivasi belajar siswa.

3) Untuk mengetahui keterlaksanaan model inquiry learning digunakan persentase keterlaksanaan model inquiry learning.

$$
P k=\frac{S}{N} \times 100 \%
$$

Keterangan:

$P k \quad=$ Persentase skor keterlaksanaan

$S \quad$ = skor yang diperoleh

$N \quad=$ skor total

Kriteria persentase keterlaksanaan dapat dilihat pada Tabel III sebagai berikut. 
TABEL III

KrITERIA PERSENTASE KeTERLAKSANAAN

Presentase $(\%) \quad$ Kriteria

$\begin{array}{cc}81,25<P k \leq 100 & \text { Sangat Baik } \\ 62,50<P k \leq 81,25 & \text { Baik } \\ 43,75<P k \leq 62,50 & \text { Kurang Baik } \\ 25 \leq P k \leq 43,75 & \text { Tidak Baik }\end{array}$

Berdasarkan Tabel 3 keterlaksanaan model inquiry learning dilihat berdasarkan kriteria sangat baik, baik, kurang baik, dan tidak baik.

\section{HASIL DAN PEMBAHASAN}

Berdasarkan pengolahan data hasil penelitian diperoleh bahwa nilai rata-rata kelas yang diajarkan dengan model inquiry learning (kelas eksperimen) lebih tinggi daripada kelas yang diajarkan dengan model pembelajaran langsung (kelas kontrol). Hal ini menunjukkan bahwa adanya perbedaan kemampuan berpikir kritis matematis siswa yang diajarkan dengan model inquiry learning dan yang diajarkan dengan model pembelajaran langsung. Hasil posttest kelas eksperimen dan kelas kontrol dapat dilihat pada Tabel IV sebagai berikut.

TABEL IV

HASIL POSTTEST KELAS EKSPERIMEN DAN KELAS KONTROL

\begin{tabular}{ccc}
\hline Statistik & Kelas Eksperimen & Kelas Kontrol \\
\hline Rata-rata & 66,19 & 56,15 \\
Nilai tertinggi & 89 & 78 \\
Nilai terendah & 44 & 39 \\
Varians & 161,84 & 125,28 \\
Standar Deviasi & 12,72 & 11,19 \\
Jumlah Siswa & 32 & 33 \\
\hline
\end{tabular}

Adanya perbedaan kemampuan berpikir kritis matematis siswa kelas eksperimen dan kelas kontrol dikarenakan siswa kelas eksperimen tidak secara langsung mendapatkan materi pembelajaran dari guru tetapi model inquiry learning menempatkan siswa sebagai subjek belajar yaitu siswa tidak hanya berperan sebagai penerima pelajaran melalui penjelasan guru secara verbal tetapi mereka berperan menemukan sendiri inti dari materi pelajaran itu sendiri. Sejalan dengan hal tersebut penelitian yang dilakukan oleh Wahyudi (2013) bahwa terdapat perbedaan yang signifikan, dilihat dari hasil berpikir kritis posttest kelas eksperiemen dengan model inquiry dan hasil posttest kelas kontrol menggunakan model pembelajaran konvensional.

Kondisi tersebut dapat terjadi dikarenakan pembelajaran dengan model inquiry menuntut siswa untuk aktif dalam proses pembelajaran. Kegiatan pembelajaran di kelas terjadi interaksi banyak arah. Model pembelajaran inquiry memberikan kesempatan pada siswa untuk mengkonstruksi pengetahuan sendiri, menggunakan konsepkonsep yang telah dimiliki untuk memecahkan masalah yang dihadapi dengan kata lain siswa mempunyai kesempatan untuk mengaitkan informasi baru dengan struktur kognitif yang ada sehingga terjadi belajar bermakna (Wahyudi, 2013: 58). Sejalan yang dikemukakan Gulo (Wahyudi, 2013: 12) model inquiry berarti suatu rangkaian kegiatan belajar yang melibatkan secara maksimal seluruh kemampuan siswa untuk mencari dan menyelidiki secara sistematid, kritis, logis, analitis, sehingga siswa dapat merumuskan sendiri penemuannya dengan penuh percaya diri.

Selanjutnya untuk mengetahui pengaruh model inquiry learning terhadap kemampuan berpikir kritis matematis siswa digunakan rumus Effect Size. Adapun hasilnya dapat dilihat pada Tabel V sebagai berikut.

TABEL V

HASIL UJI EFFECT SIZE

\begin{tabular}{ccccc}
\hline Kelas & $\begin{array}{c}\text { Nilai } \\
\text { Rata-rata }\end{array}$ & $\begin{array}{c}\text { Standar } \\
\text { Deviasi } \\
\text { Kontrol }\end{array}$ & ES & Keterangan \\
\hline $\begin{array}{c}\text { Eksperimen } \\
\text { Kontrol }\end{array}$ & 66,19 & 11,19 & 0,9 & Tinggi \\
\hline
\end{tabular}

Berdasarkan Tabel V dapat dilihat bahwa nilai Effect Size sebesar 0,9 dengan kriteria tinggi. Hal ini berarti model inquiry learning memberikan pengaruh yang tinggi terhadap kemampuan berpikir kritis matematis siswa. Hal tersebut menunjukkan bahwa adanya perubahan yang lebih baik kemampuan berpikir kritis matematis siswa setelah diterapkannya model inquiry learning. Pembelajaran dengan model inquiry memberikan kesempatan kepada siswa untuk terlibat langsung dalam proses pembelajaran. Proses-proses dalam pembelajaran inkuiri mulai dari tahapan merumuskan masalah hingga kegiatan merumuskan kesimpulan benarbenar mengajak siswa untuk dapat aktif mengikuti proses pembelajaran. Siswa diajarkan untuk berpikir secara kritis dalam menguji hipotesis yang telah dibuat untuk menemukan jawaban sementara yang sesuai dengan informasi yang diperoleh. Dalam hal ini, model inquiry learning memberikan pengaruh yang baik terhadap kemampuan berpikir kritis matematis, dimana kemampuan berpikir kritis siswa lebih baik setelah diterapkannya model inquiry learning. Hal ini sesuai dengan salah satu karakteristik yang dikemukakan oleh Sanjaya (dalam Hanif, 2010) yaitu tujuan dari penggunaan inkuiri dalam pembelajaran adalah mengembangkan kemampuan berpikir secara sistematis, logis, dan kritis, atau mengembangkan kemampuan intelektual sebagai bagian dari proses mental. Berdasarkan pernyataan tersebut dapat 
disimpulkan bahwa model inquiry learning berpengaruh terhadap kemampuan berpikir kritis matematis siswa.

TABEL VI

Hasil ANGKet Motivasi Belajar Siswa

\begin{tabular}{cccc}
\hline Kelas & $\begin{array}{c}\text { Rata-rata } \\
\text { Skor }\end{array}$ & $\begin{array}{c}\text { Persentase } \\
\text { Rata-rata }\end{array}$ & Kriteria \\
\hline Eksperimen & 65,31 & $81,64 \%$ & Sangat \\
Kontrol & 55,42 & $69,28 \%$ & $\begin{array}{c}\text { Tinggi } \\
\text { Tinggi }\end{array}$ \\
\hline
\end{tabular}

Berdasarkan Tabel VI dapat dilihat bahwa persentase ratarata kelas eksperimen memiliki kriteria sangat baik. Hal ini berarti dengan penggunaan model inquiry learning dapat mempengaruhi motivasi belajar siswa dengan kriteria sangat baik. Hal ini menunjukkan motivasi belajar siswa kelas eksperimen lebih baik daripada kelas kontrol. Siswa kelas eksperimen menunjukkan perubahan yang sangat baik dalam belajar karena adanya motivasi yang sangat tinggi.

Menurut Sudjana (dalam Badaruddin, 2015: 9) motivasi belajar siswa adalah suatu daya, dorongan atau kekuatan, baik yang datang dari diri sendiri maupun dari luar yang mendorong siswa untuk belajar. Dalam penelitian ini yang menjadi daya atau dorongan dari luar yang mendorong siswa untuk belajar adalah menggunakan model inquiry learning dalam proses pembelajaran. Sehingga dapat disimpulkan bahwa dengan penggunaan model inquiry learning dapat mempengaruhi motivasi belajar siswa dengan kategori sangat baik.

Keterlaksanaan model inquiry learning diperoleh melalui lembar observasi yang diisi oleh satu orang guru Matematika dan dua orang mahasiswa Pendidikan Matematika STKIP Singkawang. Adapun hasil observasi pada pertemuan pertama dan pertemuan kedua dapat dilihat pada Tabel VII sebagai berikut.

TABEL VII

HASIL OBSERVASI KETERLAKSANAAN MODEL INQUIRY LEARNING

\begin{tabular}{|c|c|c|c|c|c|c|}
\hline \multirow[b]{2}{*}{ Statistik } & \multicolumn{3}{|c|}{ Pertemuan I } & \multicolumn{3}{|c|}{ Pertemuan II } \\
\hline & $\begin{array}{c}\text { Observer } \\
1\end{array}$ & $\begin{array}{c}\text { Observer } \\
2\end{array}$ & $\begin{array}{c}\text { Observer } \\
3\end{array}$ & $\begin{array}{c}\text { Observer } \\
1\end{array}$ & $\begin{array}{c}\text { Observer } \\
2\end{array}$ & $\begin{array}{c}\text { Observer } \\
3\end{array}$ \\
\hline $\begin{array}{l}\text { Persentase } \\
\text { rata-rata }\end{array}$ & & $74,62 \%$ & & & $88,26 \%$ & \\
\hline Kriteria & & Baik & & & Sangat Baik & \\
\hline $\begin{array}{c}\text { Persentase } \\
\text { total }\end{array}$ & \multicolumn{6}{|c|}{$81,44 \%$} \\
\hline Kriteria & \multicolumn{6}{|c|}{ Sangat Baik } \\
\hline
\end{tabular}

Berdasarkan Tabel VII dapat dilihat bahwa persentase pada pertemuaan pertama dan kedua mengalami peningkatan. Persentase total dari dua pertemuan diperoleh hasil $81,44 \%$ dengan kriteria sangat baik. Hal ini berarti keterlaksanaan model inquiry learning terlaksana dengan sangat baik. Pada pertemuan II persentase rata-rata lebih meningkat daripada pertemuan I, hal tersebut dikarenakan peneliti telah mengevaluasi kekurangan kegiatan pembelajaran pada pertemuan I dan memperbaikinya pada pertemuan II dengan melaksanakan seluruh kegiatan sesuai dengan rancangan pelaksanaan pembelajaran yang telah dibuat. Sehingga siswa lebih merespon apa yang dilakukan guru dan merasa tertarik untuk mengikuti proses pembelajaran dengan model inquiry learning. Proses Pembelajaran dengan model inquiry learning menuntut siswa untuk aktif dalam proses pembelajaran. Kegiatan pembelajaran di kelas terjadi interaksi banyak arah. Proses pembelajaran inquiry membuat siswa lebih aktif dalam proses pembelajaran, karena siswa dapat bertanya walaupun tidak dengan guru secara langsung. Kemudian, siswa juga dituntut untuk dapat mengemukakan pendapatnya dalam tahap menarik kesimpulan. Dengan demikian, siswa tidak mungkin malu dan bertanya dan mengemukakan pendapatnya karena mereka memiliki kebebasan untuk berpendapat sesuai dengan pemikirannya, namun tetap pada jalur materi yang dipelajari. Secara keseluruhan, dapat disimpulkan bahwa persentase ratarata keterlaksanaan pada kedua pertemuan sebesar $81,44 \%$ dan memiliki kriteria sangat baik.

\section{SIMPULAN}

\section{Kesimpulan}

Berdasarkan hasil analisis data hasil penelitian dan pembahasan secara umum dapat disimpulkan bahwa model inquiry learning dapat memberikan pengaruh yang tinggi terhadap kemampuan berpikir kritis matematis siswa pada materi fungsi kuadrat kelas X SMA Negeri 3 Singkawang. Sesuai dengan sub-sub rumusan masalah penelitian, secara khusus dapat disimpulkan hal-hal sebagai berikut.

a. Terdapat pengaruh model inquiry learning terhadap kemampuan berpikir kritis matematis siswa pada materi fungsi kuadrat kelas X SMA Negeri 3 Singkawang. Hal ini dibuktikn dengan uji Effect Size diperoleh nilai Effect Size yaitu sebesar 0,9 yang berada pada kriteria tinggi. Jadi model inquiry learning memberikan pengaruh yang tinggi terhadap kemampuan berpikir kritis matematis siswa.

b. Model inquiry learning memberikan pengaruh yang lebih baik terhadap motivasi belajar siswa. Hal ini dibuktikan dari persentase rata-rata motivasi belajar siswa yang diajarkan dengan model inquiry learning yaitu sebesar $81,64 \%$ dengan kriteria sangat tinggi memiliki persentase rata-rata yang lebih tinggi daripada motivasi belajar siswa yang diajarkan dengan model 
pembelajaran langsung yaitu sebesar 69,28\% dengan kriteria tinggi.

c. Keterlaksanaan model inquiry learning terlaksana dengan sangat baik. Hal ini dibuktikan dari total persentase keterlaksanaan yaitu sebesar $81,44 \%$.

\section{Saran}

Berdasarkan hasil penelitian ini, saran dalam penelitian ini adalah:

a. Penggunaan model inquiry learning dalam proses pembelajaran dangat berpengaruh terhadap suatu proses pembelajaran. Oleh karena itu, model inquiry learning direkomendasikan untuk digunakan dalam penyampaian materi fungsi kuadrat.

b. Selama dalam proses pembelajaran berlangsung guru harus mampu mengkondisikan kelas agar tidak ada membuat keributan di dalam kelas yang dapat menggangu konsentrasi belajar siswa lain.

c. Guru dapat menjadikan model inquiry learning sebagai alternatif dalam pembelajaran matematika sehingga dapat meningkatkan kemampuan berpikir kritis matematis siswa dan motivasi belajar siswa, sehingga tujuan belajar mudah tercapai.

d. Diharapkan kepada guru yang menggunakan model inquiry learning dalam proses pembelajaran untuk melaksanakan tahapan model inquiry learning dengan baik.

e. Bagi peneliti selanjutnya, diharapkan untuk berusaha melakukan penelitian lanjutan dengan menyempurnakan kekurangan-kekurangan yang ada, karena penelitian ini masih jauh dari kesempurnaan.

\section{UCAPAN TERIMA KASIH}

Penulis mengucapkan terima kasih kepada dosen pembimbing I (Alm) Ristia Apriana, M.Pd karena dengan ilmu yang diberikan selama hidup beliau kepada penulis dapat membantu penulis menyelesaikan jurnal ini dan kepada dosen pembimbing II Rika Wahyuni, S.Si, M. Pd yang telah membimbing, memberikan saran, serta pengarahan kepada penulis sehingga penulis dapat menyelesaikan jurnal ini.

\section{DAFTAR PUSTAKA}

Badaruddin, Muhammad. (2015). Pengaruh Model Pembelajaran Problem Based Learning (PBL) Terhadap Motivasi dan Hasil Belajar IPA Biologi Siswa MTs Nurul Huda Sarimulyo Ngawen Blora. Skripsi Program Studi Pendidikan Biologi, UIN Sunan Kalijaga Yogyakarta.
Fahrunnisak, Herlina. (2014). Analisis Kemampuan Berpikir Kritis Siswa Kelas VII dalam Menyelesaikan Soal Matematika Materi Garis dan Sudut di MTsN Tunggangri. Skripsi Jurusan Tadris Matematika (TMT), Fakultas Tarbiyah dan Ilmu Keguruan, Institut Agama Islam Negeri Tulungagung.

Hanif, Mami Suryana. (2010). Pengaruh Penerapan Model Pembelajaran Inquiry Terhadap Pemahaman Konsep Matematika Siswa Kelas VIII SMP Islam Durenan Trenggalek. Skripsi Program Studi Tadris Matematika, Jurusan Tarbiyah, Sekolah Tinggi Agama Islam Negeri (STAIN) Tulungagung.

Isjoni. (2014). Cooperative Learning. Bandung: Alfabeta.

Johnson, Elaine B. (2014). Contextual Teaching and Learning. Ibnu Setiawan (Penerjemah). Bandung: Kaifa.

Lambertus. (2009). Pentingnya Melatih Keterampilan Berpikir Kritis dalam Pembelajaran Matematika di SD. Jurnal Forum Kependidikan, Vol. 28, No. 2, Maret 2009.

Riyanto, Yatim. (2012). Paradigma Baru Pembelajaran. Jakarta: Kecana Prenada Media Group.

Saputri, Nur Indah. (2014). Upaya Meningkatkan Kemampuan Berpikir Kritis Siswa Kelas V Melalui Inkuiri Terbimbing Pada Mata Pelajaran IPA di SD N Punukan, Wates, Kulon Progo Tahun Ajaran 2013/2014. Skripsi Program Studi Pendidikan Guru Sekolah Dasar, Jurusan Pendidikan Pra Sekolah dan Sekolah Dasar, Fakultas Ilmu Pendidikan Universitas Negeri Yogyakarta.

Sumarni, Margaretha Lidya. (2014). Pengaruh Metode Role Playing Terhadap Hasil Pembelajaran PKN Siswa Kelas V Sekolah Dasar. Artikel Penelitian Program Studi Pendidikan Guru Sekolah Dasar, Fakultas Keguruan dan Ilmu Pendidikan Universitas Tanjungpura Pontianak.

Syaifurahman, dan Tri Ujiati. (2013). Manajemen Dalam Pembelajaran. Jakarta: Indeks.

Wahyudi. (2013). Efektivitas Model Pembelajaran Inquiry Dalam Meningkatkan Kemampuan Berpikir Kritis Pada Kompetensi Kejuruan Pemesinan Dasar Kelas X SMK Piri 1 Yogyakarta. Skripsi Program Studi Pendidikan Teknik Mesin, Fakultas Teknik Universitas Negeri Yogyakarta. 